\title{
Ideological and Moral Construction in Building of New Socialist Countryside
}

\author{
Xiaorong $\mathrm{Mi}^{1}$ \\ ${ }^{1}$ Institute of Marxism, Southwest University, Chongqing, China \\ Correspondence: Xiaorong Mi, Institute of Marxism, Southwest University, Chongqing 400715, China. E-mail: \\ mxr1713@163.com
}

Received: June 25, 2012 Accepted: July 9, 2012 Online Published: October 18, 2012

doi:10.5539/ass.v8n13p134

URL: http://dx.doi.org/10.5539/ass.v8n13p134

\begin{abstract}
Ideological and moral construction is an internal need and important guarantee to develop socialism advanced culture and build a new socialist countryside. Hundreds of millions of farmers are not only the beneficiary of achievement of new socialist countryside building, but also are the subject power of building the new socialist countryside. Their ideological and moral condition has a direct effect on the effect of functions played by the subject power.
\end{abstract}

Keywords: building of new socialist countryside, ideological and moral construction, task, strategy

It is pointed out in the $17^{\text {th }}$ National Congress of the Communist Party of China to strengthen cultural construction, obviously enhance the whole national civilization quality and realize the struggle objective of building a well-off society in an all-around way. Building of the new socialist countryside is an important component to realize the well-off society in an all-around way. Thus, strengthening rural ideological and moral construction and enhancing the civilization quality of the vast majority of farmers is the top subject matter in building the new socialist countryside and is also the basic requirement to realize the well-off society in an all-around way.

\section{Important Role of Ideological and Moral Construction in Building the New Socialist Countryside}

\subsection{Ideological and Moral Construction Offers Intellectual Impetus for Building the New Socialist Countryside}

The hundreds of millions of farmers in China are not only the beneficiary of the achievement of building the new socialist countryside, but are also the subject power of building of the new socialist countryside. Their ideological and moral condition has a direct effect on the effect of functions played by the subject power. It is believed by the historical materialism that, social consciousness reacts up on social existence. This kind of reaction property has its double polarity. That is to say, positive and progressive social consciousness has a propelling effect on social existence and negative and backward social consciousness has an obstructive effect on social existence. Ideological and moral construction is not social consciousness in its general sense, but has the property of ideology. The ideological and moral quality of the social members of a country directly constrains consolidation and development of the economic foundation of the country. Thus, it can be seen that, it is of great significance to intensify the ideological and moral construction of social members. The word "new" in the proposition of building of the new socialist countryside has a profound and abundant connotation. It does not only refer to abundant material products and growth of economic indices, but also, as it goes without saying, implies the development of political life and improvement of cultural life. Such "new" countryside building complies with the core of human orientation in the scientific outlook on development.

\subsection{Ideological and Moral Construction Embodies the Value Appeal of Building the New Socialist Countryside}

All-around development of human being is the ultimate goal and the highest value of all social development. The scientific outlook on development by the CPC corresponds with this ultimate goal and highest value and places "human orientation" as the core of the national development. Generally speaking, the purpose of social development is to satisfy demands of the social members, which can really reflect the value and significance of development. The reason why the society is developed in an "all-around" way and in a "scientific" way is that the demand of human being is multi-dimensional and continuously transitional. Hence, the significance of ideological and moral construction is diversified in that it can not only directly serve to satisfy the need of social 
members in their ideological and moral development, but can also act on the objective world and the society per se through the practical activities of the practical subject of social members. Therefore, from this perspective, reinforcement on rural ideological and moral construction is not only the ideological guarantee and spiritual impetus of building of the new socialist countryside, but is also aimed to satisfy the spiritual and cultural demand of the hundreds of millions of farmers, and reflects the value appeal of building of the new socialist countryside.

\subsection{Ideological and Moral Construction Is the Ideological Foundation for Propelling Rural Democratic Construction}

The $17^{\text {th }}$ National Congress of the Communist Party of China also again and again emphasized persistent development of socialist democratic politics. And it also emphasized that people may directly execute the democratic rights in pursuant to the law, manage grass-root public affairs and public welfare establishments, conduct self-management, self-service, self-education, self-supervision and strengthen the function of social self-government.

Ideological and moral construction may intensify the democratic consciousness of farmers, cultivate their democratic concept, reinforce their democratic management and promote their democratic life so as to propel real realization of rural democratic management, and it is the ideological foundation of rural democratic construction. In the process of building the new socialist countryside, the vast majority of farmers are not only the major beneficiary of rural democratic construction, but are also the major participants of rural democratic construction. However, a large number of villagers have no idea about the concept of management democracy and they are still at a condition of wait and see with regards to the democratic construction of the new countryside. Ideological and moral construction may strengthen the democratic idea and democratic consciousness of the vast majority of farmers, get rid of their worries about participating in the democratic life, clear away the ideological stumbling block for them to participate in the democratic life, mobilize their enthusiasm in participating in democracy and enable them to actively and positively participate in the democratic life.

\subsection{Ideological and Moral Construction Is the Necessary Condition to Propel Rural Civilization Construction}

The five overall requirements for building of the new socialist countryside that were proposed in "Suggestions of Outline of the Eleventh Five Years Plan" contain "rural civilization". Rural civilization is reflection of the quality of farmers and embodies the requirement for rural spiritual and civilization construction. Only when the ideological, cultural and moral level of farmers is continuously improved, and only if they uphold civilization, respect science, form family harmony, act in a simple and honest manner, collaborate and cooperate with each other, form a stable and harmonious social atmosphere, and only if sports, culture, sanitation, and sports are vigorously development, can the building new countryside is comprehensive and complete. Propelling construction of rural civilization is an important aspect of rural ideological and rural construction, and, meanwhile, is the functional advantage of rural ideological and moral construction. Ideological and moral construction helps to advocate farmers to respect science, to have integrity and abide by the law, to resist the superstition, to transform social traditions, to follow the basic code of ethics of citizens, to form a healthy and civilized life style, to form equality of men and women, to respect the old and cherish the young, to form harmony in the neighborhood, to achieve prosperity through hard work and to support the poor and the impoverished.

\section{Major Content of Strengthening Rural Ideological and Moral Construction at a New Period}

It was pointed out in the Third Plenary Session of the $17^{\text {th }}$ Central Committee of CPC, "It is necessary to persist in resorting to advanced socialist culture to occupy the rural battlefield to satisfy the increasing spiritual and cultural demand of farmers and to enhance the ideological and moral quality of farmers. It is necessary to solidly carry out construction of socialist central value system, adhere to arm rural CPC members and educate peasant public with the socialist theory system with Chinese characteristics and direct farmers firmly establish the ideas of patriotism, collectivism and socialism." This offers us the basic foundation to confirm content in conducting rural ideological and moral education.

\subsection{To Strengthen Education of Ideal and Belief on the Vast Majority of Farmers}

Ideal is a highly self-conscious self awareness that people surpass the reality, go beyond themselves and pursue an ambitious value target in the future and is the perfect ambitious value target system in the future that is designed after prediction and that people struggle for. Belief is stable self-awareness that people surpass the reality, go beyond themselves and firmly believe in a beautiful achievement of the future on the basis of firmly belief in the truth and identification of the value and is stable and long-lasting concept that is firmly believed to 
be true and to produce a beautiful achievement.

Ideal and belief are the highest value pursuit of a subject and are the spiritual pillar that govern people's soul. They are the moral foundation of people. There would be a common value target if there is a common ideal belief and there would be strong spiritual motive if there is ideal and belief.

The common ideal of Chinese people is to construct socialism with Chinese characteristics and the loftiest political belief is Marxism and Communism. Strengthening ideal and belief education among the vast majority of farmers at present refers to education of Marxism, Mao Zedong Thought and socialist theory system with Chinese characteristics and the education of patriotism, collectivism and world outlook, outlook on life and concept of value.

\subsection{To Strengthen Moral Education on the Vast Majority of Farmers}

Morality is a sort of social ideology and is a norm and standard for the common life and behavior of people. It is determined by certain social and economic foundation and it serves for certain social and economic foundation. The moral concept of human being is affected by certain acquired production relationship and social public opinions and is gradually formed. Different times and different classes tend to have different moral concepts.

With proceeding of the reform and opening up and the vigorous propelling of the new countryside building, the mental attitude of farmers has had great improvement. However, compared with the economic development, the spiritual and cultural life in rural areas is backward for a long time and the traditional moral standard and habits not only have quintessence, but also have dross. Under the influence of the traditional morality, farmers not only have the positive side of hardworking, simplicity, integrity, respecting the old and cherishing the young, respecting and loving each other, but also have the negative side of ancestral idea, nepotism concept and feudal superstition. This presents a realistic and urgent demand on the moral education of citizens. In order to strengthen moral education of citizens, it is especially necessary to pay attention to the moral education of citizens and focus on cultivating farmers' social public morality, occupational morality and family virtues, which helps to promote building of the new socialist countryside.

\subsection{To Strengthen Legal Education on the Vast Majority of Farmers}

Strengthening legal education is an important and arduous task of ideological and moral education at a new period. Strengthening legal education among the vast majority of farmers relates to stability of rural society and successful realization of the task of building the new socialist countryside. The aim of conducting legal education among the farmers is to enable the vast majority of farmers to know about the legal rights they are entitled to obtain and the legal obligations they are supposed to abide by. Currently, the major content of legal education among the vast majority of farmers includes the following three aspects. In the first place, it is to conduct education about laws and regulations in basic rights and obligations of citizens based on the constitution, such as, Law of Election, Village Committee Organization Law, General Rule of the Civil Law, Law of Marriage, Law on the Guarantee of Rights and Interests of Women, Law of Population and Family Planning, Law of Succession, Law of Adoption and Law on Compulsory Education, etc., further strengthen consciousness of rights and obligations of the vast majority of rural cadres and public and set up and maintain authority of the law. In the second place, it is to conduct education about laws and regulations in agricultural production and rural market economy, such as, Act of Agriculture, Land Administration Law, Forest Law, Water Law, Law on Land Contract in Rural Areas, Seed Law, Contract Law, Company Law, Consumer Rights Protection law, and Product Quality Law, etc., and further facilitate completeness and soundness of legal order of rural market economy. In the third place, it is to conduct education about laws and regulations in maintaining rural social public security and farmers' living security, such as, Law of the Road Traffic Safety, Food Safety law and Fire Protection Law, etc., and enhance the security precaution consciousness and ability of rural public.

\section{To Strengthen Ideological and Moral Construction and to Promote Strategy for New Countryside Construction Progress}

\subsection{To Positively Innovate the Ideological Job in Rural Areas}

Building of the new countryside and cultivating of new farmers is a vital matter that has never occurred throughout the history of China, which brings opportunities to the ideological and moral construction of rural areas and makes rural ideological and moral construction faced up with austere challenges. With continuously proceeding of the building of the new countryside, the rural economic situation, political situation and the ideology of farmers have all taken great changes. All this requires the ideological and moral construction in rural areas to adapt to the requirement of development, adhere to liberation of thought, keeping pace with the times and pioneering and innovation, continuously study the rules of rural ideological and moral construction, explore 
the direction of its development, make theoretical innovation and make use of different means to realize comprehensive progress of rural ideological and moral construction.

Firstly, it is necessary to carry forward the spirit of keeping pace with the times. Keeping pace with the times is the property of Marxism theory. In order to conduct ideological and moral construction in rural areas, it is a must to adhere to the spirit of keeping pace with the times. This requires ideological and moral constructors in rural areas to be correctly aware of the influences of reform and developmental practices on the ideology of farmers, catch the ideological tendency of farmers and grasp the pulse of changes of the times. The ideological understanding of ideological and moral constructors should firstly be liberated from those inopportune concepts. Instead, they should be good at improving their understanding in the process of liberating their thought and guide practice of rural ideological and moral construction in a view of development. Secondly, it is necessary to strengthen theoretical innovation. Theoretical innovation is the premise for rural ideological and moral construction, as theoretical innovation on the basis of practice is the forerunner of changes in rural ideological and moral construction development. This requires rural ideological and moral constructors to be good at observing and analyzing new situations and new problems in rural areas in the process of conducting rural ideological and moral construction, and explore the internal rules of its development under guide of the Marxism theory so as to promote vigorous development of rural ideological and moral construction thought. Thirdly, it is necessary to innovate the working method. Working method should change with changes of practice and develop with development of practice. Rural ideological and moral construction should try to innovate the working method so as to adapt to enormous changes in the situation of rural ideological and moral construction.

\subsection{To Set up and Complete a Long-acting Working Mechanism}

Building of the new countryside is a complex systematic project and building of the new countryside proposes newer and higher demand on the long-acting working mechanism in rural ideological and moral construction. In the first place, it is necessary to set up and complete the decision-making mechanism in rural ideological and moral construction. Successful rural ideological and moral construction can not go without scientific and rational decision making and management. And only when we set up and complete the responsibility mechanism, can decision making of rural ideological and moral construction guarantee scientificalness and rationality to the largest extent. This requires us to change the former perceptual experience and the mode of personal decision making, set up and continuously improve the decision making mechanism of going deep into the conditions of the people, extensively centralize the intelligence of the people and practically cherish the resources of the people in the process of ideological and moral construction and realize scientificalness and democratization of decision making. In the second place, it is necessary to construct and improve the security mechanism of rural ideological and moral construction. The experience of rural ideological and moral construction indicates that construction and improvement of the security mechanism is an objective requirement of rural ideological and moral construction development. Strengthening the security mechanism of rural ideological and moral construction and continuously enlarging vigor of fund investment can promote the process of rural ideological and moral construction and lay a solid material foundation for rural ideological and moral construction. In the third place, it is necessary to set up and improve the supervision mechanism of rural ideological and moral construction. As a result of the actual situation in the current rural ideological and moral construction, ideological and moral construction is seldom regarded as an important index of assessment in the grass-root political regime, which leads to weakening of rural ideological and moral construction. Therefore, it is necessary to set up and improve the supervision mechanism of rural ideological and moral construction.

\subsection{To Vigorously Develop Rural Education}

For quite a long time, the backwardness of rural education level has constrained development of rural ideological and moral construction. Thus, in order to promote the ideological and moral construction in rural areas, it is a must to take a variety of measures to develop the education in rural areas. At the same time, it is necessary to enlarge the ratio of ideological and moral construction in all kinds of education so as to make the ideological and moral construction develop shoulder to shoulder with rural education. Firstly, it is to improve rural educational system. It is necessary to enhance the compulsory education in rural areas and popularize and promote nine-year compulsory education, it is also necessary to put strength to develop occupational and technical education in rural areas and let farmers learn what they should learn. Meanwhile, we have to pay attention to organic combination of occupational education with ideological and moral construction in rural occupational and technical education and regard the course of ideological and moral cultivation as part of daily teaching. secondly, it is necessary to strengthen support strength on development of rural education and enlarge investment in rural educational development. In order to develop education in rural areas, it is a must to enlarge educational investment in rural areas. And at the time when we enlarge investment to improve the hardware facilities in rural 
education, it is more necessary to enlarge development of "software" in rural education and offer solid material guarantee for rural ideological and moral education.

\subsection{To Vigorously Develop Rural Culture and Build up Rural Harmonious Cultural Atmosphere}

With increasing diversified spiritual and cultural demand of the public in multiple aspects and at multiple levels, it is required to enhance rural ideological and moral construction and take active measures to build up a perfect atmosphere for rural ideological and moral construction. In the first place, the government should play its leading role and take into overall consideration of the service mechanism, facility, institution and team construction of rural cultural undertakings. The government should lay special emphasis to the infrastructure construction of township cultural stations and fully play the subjective and leading role of state-own cultural institutions. At the same time, the government ought to extend the objects of service and the level of service, set up and gradually improve township movie theater, cultural recreation room and rural reading room and enable farmers to share cultural service nearby their home. In the second place, it is necessary to actively conduct cultural activities, promote harmonious rural construction, enrich the cultural life of the public and persistently resist influences of decayed and backward culture. we have to vigorously develop education of socialist honor and dishonor in rural areas and enhance the ideological and moral level of farmers in a comprehensive way; we need to strengthen education of world outlook, outlook on life and concept of value among farmers and strengthen their immunological competence to resist decayed thought and influences; we have to strengthen education of social public ethics, professional ethics and family virtue among farmers and direct them to behave as a social citizen with moral integrity. In the third place, it is necessary to strengthen rural cultural team construction and pertinently develop scientific and cultural service. We have to intensify reform of personal system, invigorate rural cultural management mechanism and recruit professional cultural management personnel. We have to encourage and support farmers in spontaneous organizing cultural associations and performing teams and reinforce business guidance. We have to help rural areas to make a good job of cultural team construction and business exchange and spontaneously cultivate rural talents by means of holding a variety of cultural activities. In general, it is necessary to activate and optimize rural cultural atmosphere through a variety of approaches, influence unconsciously the thought of farmers and lay a solid cultural foundation for proceeding of rural ideological and moral construction.

\section{References}

Li, Q. (2007). Cultivation of New Type of Farmers Is the Basis and Premise of Building the New Socialist Countryside. Marxism \& Reality, (5).

Qi, F. X. (2009). Village Civilization Construction in the Process of New Countryside Building. The Journal of Shandong Agricultural Administrators' College, (1).

Wang, B. Y. (2010). The Role of Government in the Ideological and Moral Construction of New Countryside. Forward Position, (22).

Zhang, H. X. (2008). Discussion on Ideological and Political Education of Farmers in Rural Ecological Civilization Construction. Mao Zedong Thought Study, (4).

Zhou, D. X. (2011). Discussion on the Integration Function of Marxism Culture in Cultural Building of New Countryside. Forward Position, (19). 